\title{
Taanit bechorim (Fast of the first-born) in rabbinic judaism
}

\section{[,Taanit bechorim“ (pust prvorozenych) v rabinskem judaismu]}

\author{
Roman Kralik - Marie Roubalova - Ladislav Lenovsky - Tunde Tuska - \\ Sandra Kralj-Vuksic
}

DOI: 10.18355/XL.2018.11.02.02

\begin{abstract}
:
The presented study describes the importance and meaning of fasting in relation to God. This is a special way of calling to God in the limiting situations of man - in times of grief, anxiety, fear and pain. Fasting is also a reminder and presentation of ancient national disasters in Israel. Fasting of the first-born is an important event that every year before Pesach reminds firstborn Israelites their redemption and salvation at the slaughter of the firstborn in Egypt.
\end{abstract}

Key words: man, fasting, Israel, God

\section{Anotace:}

Předložená studie opisuje důležitost a význam půstu ve vztahu k Bohu. Jde o zvláštní způsob volání $\mathrm{k}$ Bohu v mezních situacích člověka - v době zármutku, úzkosti, strachu a bolesti. Půst je také připomínkou a zpřítomněním dávných národních katastrof Izraele. Půst prvorozených je významnou událostí, která každoročně před svátkem Pesach připomíná prvorozeným synům Izraele jejich vykoupení a záchranu při pobíjení prvorozených v Egyptě.

Klíčová slova: člověk, půst, Izrael, Bůh

\section{Úvodem}

Půst hebrejsky: „taanit“ (v tanachické hebrejštině: „trýzeň“, „trápeni““; v pozdější hebrejštině: ,půst“) je substantivum odvozené od hebrejského slovesa: „ana“" (,byl pokořený“, „byl pokorný“, „byl ztrápený") „,com“ - (půst) je substantivum odvozené od hebrejského slovesa „,cam“ (,postil se“). - zdržení se jídla (někdy také pití) po určitou dobu - je podle Tóry jedním z projevů pokoření člověka před Bohem. (Vajikra 16,29; 23,27; Bemidbar 29,7).

Jde o zvláštní způsob volání $\mathrm{k}$ Bohu - především v mezních situacích člověka - v době zármutku, úzkosti, strachu a bolesti. Velmi inspirativní je dánský myslitel Søren Kierkegaard, který se právě o těchto tématech napsal množství knih např.: Koncept úzkosti, Nemoc k smrti, Bázeň a chvění a další. Margarette Susman napsala: “Židovský problém je židovské utrpení a to, že jej národy Evropy odmítly a zavrhly. Celý svět je ale dmes jediný proud utrpení, národních tragédií i lidských osobních utrpení. Je to chaos utrpení a hrůzy." (SUSMAN, 1996: 48)

Tyto situace a pocity ochromují člověka v jeho každodenních činnostech:

„Člověk, kterého postihla bolest, ji pocituje velmi hluboce, je jí úplně ochromen, vnitřně pohlcen, zcela prosycen... Nemyslí na nic jiného než na svůj zármutek a jeho přičiny. Tyto myšlenky vyžaduji jeho veškerou pozornost a dokáži otupit všechny ostatni pocity i tělesné potřeby... Skličený člověk odmitá cokoli pojist... " (VRIES, 2008: 133).

V některých př́ípadech je půst také připomínkou a zpř́tomněním dávných národních katastrof Izraele, které tyto tíživé a bolestné pocity člověka v minulosti vyvolávaly.

XLinguae, Volume 11, Issue 2, April 2018, ISSN 1337-8384, eISSN 2453-711X 
Zejména obležení Jeruzaléma králem Nabúkadnesarem v desátém měsíci (Melachim bet 25,1), dobytí Jeruzaléma ve čtvrtém měsíci (Melachim bet 25,3-4), zničení jeruzalémského chrámu v pátém měsíci (Melachim bet 25,8-9), zavraždění Gedaljáše a jeho mužů v sedmém měsíci (Melachim bet 25,25).

Posty jsou v rabínském judaismu různorodé. Nejvýznamnější jsou posty výroční, které se vztahují k nejtragičtějším událostem dějin vyvoleného národa (nejvýznamnější z těchto postů je předexilní půst „Tiša beav“, kterým si židé prripomínají zničení jeruzalémského chrámu a další truchlivé události, které je v jejich historii potkaly:

“To bude pro vás provždy platné nařízení. Desátého dne sedmého měsíce se budete pokořovat a nebudete vykonávat žádnou práci, ani domorodec ani ten, kdo mezi vámi přebývá jako host. $30 \mathrm{~V}$ tento den za vás vykoná smírčí obřady a očistí vás ode všech vašich hříchů. Budete před Hospodinem čisti. Bude to pro vás den odpočinku, slavnost odpočinutí. Budete se pokořovat. To je provždy platné nařízení." (Vajikra 16,29-31)

"Desátého dne téhož sedmého měsíce bude den smíření. Budete mít bohoslužebné shromáždění; budete se pokořovat a přinesete ohnivou obět' Hospodinu. Toho dne nebudete konat žádnou práci. Je to den smírení, kdy se za vás budou konat smírčí obřady před Hospodinem, vaším Bohem. Kdo se toho dne nebude pokořovat, bude vyobcován ze svého lidu. Kdyby někdo konal toho dne nějakou práci, vyhubím ho ze společenství jeho lidu. Nebudete vykonávat žádnou práci! To je provždy platné nařízení pro všechna vaše pokolení ve všech vašich sídlištích. Bude to pro vás den odpočinku, slavnost odpočinutí; budete se pokořovat od večera devátého dne toho měsíce, od jednoho večera do druhého budete zachovávat svůj den odpočinku." (Vajikra 23,27-32)

"Desátého dne toho sedmého měsíce budete mít bohoslužebné shromáždění a budete se pokořovat. Nebudete vykonávat žádnou práci." (Bemidbar 29,7) a další pravidelné posty napřr. půst Esteřin (Ester 9,31). Tyto posty se týkají celé pospolitosti (,taanit cibur").

Kromě toho jsou praktikovány také př́ležitostné posty, jak individuální (půst ženicha a nevěsty před svatbou, půst v den výročí úmrtí rodiče, půst po zlém snu), tak také posty obce (například dojde-li nedopatřením k nešetrnému zacházení se svitkem Tóry) nebo oblasti (v době sucha či epidemie).

Jedním z mnoha židovských postů je „taanit bechorim“ (,půst prvorozených“). (Tur 429, 470; Mišna berura 470.7). Mišna doporučuje, aby se všichni (nikoliv pouze prvorození) postili od odpoledne do večera den před svátkem Pesach, tedy v době, kdy se koná půst prvorozených. (Mišna, Pesachim 10,1)

Podle Talmudu Rabi Jehuda Hanasi tento den ,nejedl ani kvašené ani nekvašené“ (JT, Pesachim 10,1) a v této době se postil také rav Šešet (BT, Pesachim 108a). Traktát Sofrim uvádí, že v měsíci nisan se nepostíme, protože je to měsíc vykoupení s výjimkou prvorozených, kteří se postí na „erev Pesach“ (Masechet sofrim 21,3). Okrajově tento půst zmiňuje i Jeruzalémský talmud v traktátu Pesachim (JT, Pesachim 68b, tento text je však často zpochybňován). (NOSEK - DAMOHORSKÁ, 2010: 259).

Půst před svátkem Pesach byl zpočátku dáván do souvislosti především $\mathrm{s}$ pesachovou večeří. A byl zdůvodňován tím, že účastníci pesachové večeře si po postu mohli lépe vychutnat maso beránka, nekvašený chléb, hořké byliny a další jídla.

V pozdější době byl v souvislosti s postem prvorozených více akcentován motiv záchrany prvorozených Izraele v Egyptě. (Šemot 12-13; BT, Masechet sofrim 21,2; Mišna berura 470,1; Kaf hachajim 470,1.30; Tur 470,1).

\section{Termín konání půstu prvorozených}


Půst prvorozených se koná čtrnáctého nisanu, tj. den před svátkem Pesach (,erev Pesach"). (Kicur šulchan aruch 107,2). A to i přesto, že měsíc nisan je všeobecně považován za měsíc, v němž se posty nemají konat (viz výše). (BT, Pesachim 68b; Masechet sofrim 20,3). Půst prvorozených se přesouvá v př́padě, že Pesach připadá na neděli a půst by tak připadl na šabat (např́íklad v letech: 5741, 5754, 5765, 5768), protože v sobotu je půst zakázán (s výjimkou Dne smíření - Jom kipur).

Podle názoru některých rabínů se $\mathrm{v}$ tomto případě půst nepřesouvá, nýbrž ruší. Zvykem je však přesunout půst na čtvrtek nebo se tento den účastnit sijumu (Šulchan aruch 470,2; Rama 470,2).

Přesunutí postu na nejbližší možný termín (pátek) by mohlo působit problémy při přípravách na šabat, proto je obvyklé přesunout půst na čtvrtek. (Rama 470,2. V prŕípadě, že půst prvorozených připadne na pátek, nepřesouvá se (Mišna berura 470,5). Tímto způsobem (tedy na předchozí čtvrtek) se přesouvá také Esteřin půst, když připadne na šabat. (BT, Megila 5a) Půst „Teša be av“ (9. av) se oproti tomu (v príípadě, že připadne na šabat) přesouvá na neděli, protože není vhodné připomínat si neštěstí dříve, než $\mathrm{v}$ den na který skutečně připadá. $\mathrm{V}$ této souvislosti lze namítnout, že půst prvorozených také připomíná neštěstí (pobíjení prvorozených v Egyptě):

"Až se vás pak vaši synové budou ptát, co pro vás tato služba znamená, odpovíte: »Je to velikonoční obětní hod Hospodinův. On v Egyptě pominul domy synů Izraele. Když udeřil na Egypt, naše domy vysvobodil.« Lid padl na kolena a klaněl se. Izraelci pak odešli a učinili přesně tak, jak Hospodin Mojžišovi a Áronovi přikázal. Když nastala půlnoc, pobil Hospodin $\mathrm{v}$ egyptské zemi všechno prvorozené, od prvorozeného syna faraónova, který seděl na jeho trůnu, až po prvorozeného syna zajatce v žalářní kobce, i všechno prvorozené z dobytka." (Š́émot 12, 26-29)

$\mathrm{Z}$ tohoto důvodu mohou mezi lidmi vznikat pochybnosti, zda mají půst přesunout na čtvrtek nebo na neděli. Tato nejistota existovala již v talmudické době, zejména proto, že ,erev Pesach“ a tím i půst prvorozených připadá na šabat vždy po poměrně dlouhé době. Talmud zmiňuje, že dokonce mnozí významní tanaim si nebyli jisti, jak tuto situaci řešit. (BT, Pesachim 66a). Půst prvorozených, obdobně jako půst Esteřin, připomíná zázračnou záchranu Židů.

$\mathrm{Z}$ tohoto důvodu většina autorit $\mathrm{v}$ otázkách halachy doporučuje jeho přesunutí na čtvrtek, (Rama 480,2) případně připouští možnost nepostit se vůbec. V tomto případě však rabíni doporučují účastnit se „sijumu“ (dokončení /čtení traktátu). (Šulchan aruch, Orach chajim 470,2; Kaf hachajim 470,3). „Sijumu“ se může účastnit prvorozený syn po ranní bohoslužbě (šacharit) v synagóze a pak je od postu osvobozen a může se účastnit sváteční hostiny (seuda). (Kicur šulchan aruch 113,6; Mišna berura 470,10).

„Sijum“ je slavnostní dokončení studia talmudického traktátu, sederu Mišny nebo celého Talmudu (někteří učenci se domnívají, že stejnou hodnotu má i ukončení čtení knihy Tanachu, když kniha byla studována soustavně a s hlavními komentáři).(Rama 679; Igrot Moše 1,$157 ; 2,12$ ). V této otázce se však všechny halachické autority neshodují. Nejistá je také forma studia, která osvobozuje od postu prvorozených. Někteří rabíni se domnívají, že stačí i pasivní účast, jiní trvají na tom, že prvorozený se musí na studiu sám aktivně podílet a studovanému textu musí rozumět. (Blíže viz: Aruch hašulchan 470,5; Mišna berura 470,4; Magen Avraham 470,1; Chajej Adam 129,12).

V obci by se neměla odkládat oslava „sijumu“ tak, aby připadla na den půstu prvorozených (i když je to obvyklá praxe). Obce, které uspořádají dokončení čtení traktátu jen jednou v roce, právě na den půstu prvorozených, mohou být nařčeny z toho, že se jen chtějí vyhnout dodržování půstu. Od postu prvorozených je osvobozen také ten, kdo se účastní obřízky (,berit mila“). (Magen Avraham 470; Kicur šulchan aruch 113,6). Rovněž ženich se nepostí po dobu sedmi dní od svatby.

XLinguae, Volume 11, Issue 2, April 2018, ISSN 1337-8384, eISSN 2453-711X 
Půst prvorozených začíná ráno úsvitem a končí přibližně čtyřicet minut po západu slunce nebo začátkem hostiny uspořádané na oslavu dokončení četby traktátu (,sijum“).

\section{Význam názvu a náboženský obsah půstu prvorozených}

Název postu „taanit bechorim“ (půst prvorozených) odkazuje na ty, kterých se půst především týká. Půst musí dodržovat prvorozený syn otce (prvorozenství se v tomto případě určuje vzhledem k otci i matce (na rozdíl od obřadu „pidjon haben“ vykoupení /prvorozeného/ syna, který se týká pouze prvorozeného syna matky a nikoliv prvorozeného syna otce) i prvorozený syn matky Šemot raba 18,3. Za prvorozeného syna je $\mathrm{v}$ tomto př́padě (na rozdíl od obřadu „pidjon haben“) považován i syn, kterému předcházel potrat matky, (Mišna berura 470,2; Kicur šulchan aruch 113,6 ) v př́padě, že $\mathrm{v}$ předchozím manželství porodila prvorozeného syna). Půst dodržuje prvorozený otce i prvorozený matky, protože podle rabínské tradice v Egyptě umírali jak prvorození otců tak i prvorození matek. (Mišna berura 470,2; Kaf hachajim 470,2).

Prvorozený syn dodržuje půst až od chvíle, kdy dosáhl věku dospělosti („,bar micva“). (Kicur šulchan aruch 113,6). Za mladšího syna, který ještě není dospělý (před „bar micva“) se postí otec (nebo se účastní „sijumu“) nebo matka (v př́padě, že otec je rovněž prvorozený a musí dodržovat půst za sebe). (Kicur šulchan aruch 113,6; Rama 470,2).

Podle názoru některých rabínů se může otec postit za sebe i za svého prvorozeného syna a matka se $\mathrm{v}$ tomto př́padě podle jejich názoru postit nemusí. (Mišna berura 470,9). Prvorození kněží a levité se tento den rovněž postí (existuje i menšinový názor, že jsou od postu prvorozených osvobozeni). (Mišna berura 470,2, Piskej tešuvot 470,2) Druhorozený syn se postit nemusí a to ani v př́ípadě, že prvorozený syn zemřel (za předpokladu, že se prvorozený syn dožil minimálního věku třiceti dnů a byl vykoupen). (Mišna berura 470,2)

Syn, kterého matka porodila císařským řezem, i když se narodil jako první, nemá status prvorozeného, nemusí být vykoupen, nemá nárok na dvojnásobný díl dědictví a nemusí dodržovat půst prvorozených. (Kaf hachajim 470,3). Někteří učenci však i $\mathrm{v}$ tomto př́ipadě půst doporučují. (Chok Jaakov 470,2) Poskim se neshodují v tom, zda se musí postit prvorozený konvertita. Zpravidla v tomto př́padě doporučují účast na hostině po dokončení čtení traktátu (,,sijum“").

Muži velmi horliví ve víře, kteří nejsou prvorození, mohou dodržovat tento půst dobrovolně. (Masechet sofrim 21,3). Prvorozené ženy se tento den, podle názoru některých rabínů, postit nemusí, (Rama 470,4) podle jiných by se měly postit i prvorozené ženy, (Śulchan aruch 470,1) protože v Egyptě umírali prvorození muži i ženy. (Šemot raba 18,3; Pesikta derav Kahana 7; BT, Pesachim 108b; Mišna berura 470,2.3; Kaf hachajim 470,2).

V praxi se aškenázské ženy zpravidla nepostí. (Rama 470,1; Mišna berura 470,4) Oproti tomu některé sefardské ženy tento půst zachovávají, i když ani mezi nimi není tento zvyk př́liš rozšířen. (Kaf ha chajim 470,17; Šulchan aruch 470,1) Postit by se neměly ženy těhotné a kojící, aby neohrozily život svůj či život svého dítěte. (Mišna berura 470,9; Kaf hachajim 470,15.21).

Nemocní a staří lidé, kteří cítí, že by jim zachování půstu způsobilo zdravotní potíže či slabost mohou půst přerušit nebo jsou od postu zcela osvobozeni. Protože půst by jim mohl zabránit $\mathrm{v}$ plné účasti na oslavě svátku Pesach nebo by prŕliš spěchali s čtením pesachové hagady, aby se rychle dostali k jídlu.

Bolest (např. hlavy či očí) prvorozeného člověka od půstu osvobozuje. (Mišna berura 470,2) V tomto prrípadě by prvorození měli jíst pouze lehká jídla (zejména ovoce a zeleninu), ale neměli by jíst moučná jídla. (Mišna berura 470,2; 471,3). 
Někteří rabíni zakazují jíst chléb, zatímco jiná jídla, která obsahují mouku, konzumovat dovolují. (Aruch hašulchan 470,3). Chléb není dovoleno jíst (zejména v odpoledních hodinách), aby prvorození účastníci sederové večeře měli chut' na pesachové nekvašené chleby (,macesy“). (Šulchan aruch, Orach chajim 471,1).

Název „půst prvorozených“ určuje nejen to, koho se půst týká, ale odkazuje také na záchranu prvorozených $\mathrm{v}$ domech označených krví pesachového beránka, kteří nezahynuli, když dopadla poslední egyptská rána. (Šemot 12,26; 13,14-15; Tur 470; Chatam sofer, Pesachim 108a).

Byla to velká a strašná noc, ale izraelské prvorozené Hospodin ušetřil. Od této noci však patří jemu, jsou jeho nezpochybnitelným majetkem. Zasvěcení prvorozených Bohu je ustanoveno v knize Šemot: „Posvět’ mi všechno prvorozené, co mezi Izraelci otviŕá lůno, at'z lidí či z dobytka. Je to moje!" (Šemot 13,2 srv. 22,8.).

Jejich vykoupení je přikázáno v knize Bemidbar:

„,Mně patři všechno prvorozené mezi Izraelci, člověk i dobytče. Oddělil jsem je pro sebe jako svaté $v$ den, kdy jsem pobil v egyptské zemi všechno prvorozené." (Bemidbar 8,17)

„Všechno, co z veškerého tvorstva otvirá li̊no a co se přináší v obět' Hospodinu, jak z lidi, tak z dobytka, bude tvoje; avšak prvorozené z lidí bezpodminečně vyplatíš, také vyplatiš prvorozené z nečistého dobytka. 16 Budeš je vyplácet od stárí jednoho měsice; výplatné se bude vyměrovat ve střibře: pět šekelů podle váhy určené svatyní; jeden šekel je dvacet zrn." (Bemidbar 18,15-16).

Prvorození muži vykoupení třicátý první den po svém narození při obřadu ,pidjon haben“, si každoročně tímto postem připomínají skutečnost, že patří Bohu.

\section{Závěr}

Půst prvorozených je významnou událostí, která každoročně před svátkem Pesach připomíná prvorozeným synům Izraele jejich vykoupení a záchranu při pobíjení prvorozených $\mathrm{v}$ Egyptě. Nejde o pouhou vzpomínku na událost z velmi dávné minulosti.

Vnímání času bylo pro starověké Izraelce zcela jiné. Každý, kdo se účastnil pesachové večeře, byl Hospodinem vyveden z egyptského otroctví. Nikoliv jeho pradávný předek, ale on sám byl zachráněn krví beránka před záhubou.

Jednou v roce si prvorození synové více než kdy jindy uvědomují, jaké výsady i povinnosti jim jejich prvorozenství přináší. Právě oni budou reprezentovat rodinu po smrti otce před Bohem, budou hlavním modlitebníkem (ve starých dobách i obětníkem) rodiny. Budou nositeli tradic, které převzali od svých předků, a právě jen na nich spočine zvláštní Boží požehnání. Jejich prostřednictvím se má toto požehnání šíriit do celého světa. Půst jim pomůže procítit, že musí být vzorem pro ostatní.

Prvorozenství je v neposlední řadě (podobně jako šabat a obřízka) znamením, které připomíná smlouvu mezi Hospodinem a jeho lidem - Izraelem, který je jeho prvorozeným mezi národy. „Toto praví Hospodin: Izrael je můj prvorozený syn.“ (Šemot 4,22).

Prvorozeného syna, který svou zodpovědnost za rodinu i lid necítí a pohrdá ji, čeká obdobný osud jako Ezaua, který své prvorozenství prodal Jákobovi:

„, Dej mi zhltnout trochu toho červeného, toho krvavého, jsem znaven k smrti." Proto se jmenuje Edóm (to je Červený). Jákob však řekl: "Prodej mi dnes své prvorozenství!" Ezau na to odvětil: "Stejně mám blízko k smrti, k čemu je mi prvorozenství!" Jákob řekl: "Odpřisáhni mi to dnes." A on mu to odpřisáhl, a tak své prvorozenství prodal Jákobovi. Jákob dal pak Ezauovi chléb a čočkovou krmi. Ten pojedl, napil se, vstal a odešel. Tak Ezau pohrdl prvorozenstvím.” (Berešít, 30-34).

XLinguae, Volume 11, Issue 2, April 2018, ISSN 1337-8384, eISSN 2453-711X 
This article was published with the support of Slovak Research and Development Agency under the contract No. APVV-16-0016".

\section{Bibliographic references}

ASHER, Y. 1957, Arba'ah turim. Anton Shmid.

Bible, Pismo svate Stareho a Noveho zakona vcetne deuterokanonickych knih. 1991. Cesky ekumenicky preklad. Praha: Zvon.

ELLIGER, K. RUDOLPH, W. (ed.) Tora Neviim uchtuvim. Biblia Hebraica Stuttgartensia. Editio Funditus Renovata. Stuttgart: Deutsche Bibelgesellschaft, 1990. GANZFRIED, S. 2011. Kicur sulchan aruch. Agadah. ISBN 978-80-87571-00-2.

GANZFRIED, S. 2012. Kicur sulchan aruch. II. Agadah. ISBN 978-80-87571-01-9.

HIGGER, M. (ed.) 1937. Massekhet Soferim. New York: De-Be Rabbanan.

Mikraot gedolot: hamishah humshe Torah im Targum Onkelos veim shenayim vearbaim perushim. I. - V. 1912. Vilna: Ram.

MAIMON ben Mose (Maimonides). 1989. Mishneh Torah, Hilchot Yesodei HaTorah. The Laws, Which Are the Foundations of the Torah. Moznaim Pub Corp, ISBN: 9780940118416.

RABINOVITCH, M. 2006. The Mishnah. New York: Mesorah Publications, Ltd.

Sefer Misna berura ve-hu perus jafe u-menupe al Sulchan aruch Orach chajim. Machon da' at Josef, 1994.

SOFER, Y. Ch. - KAF HACHAIM, I. - X., Jerusalajim: Hotzaat Machon HaRishonim, 1905.

Talmud Bavli. 1997. The Schottenstein Daf Yomi Edition. New York: Menorah Publications, Ltd.

CARASIK, M, 2005. The Commentators' Bible, the JPS Miqraot gedolot, Michael Carasik (ed.), Philadelphia, Jewish Publication Society.

NOSEK, B. - DAMOHORSKA, P. 2010. Zidovske tradice a zvyky. Praha: Karolinum ISBN 978-80-246-1518-9.

ROUBALOVA, M - KRALIK, R. 2016. Svaté dny židovského kalendáře (Luach hašana). APOKALIPSA. Ljubljana. ISBN 978-961- 6894-85- 2.

SKOLNIK, F. - BERENBAUM. M. 2007. Encyclopedia Judaica. 2. Vyd. Thomson Gale, Keter Publishing House LTD: Jerusalem. ISBN: 0028659287

SLADEK, P. 2008. Mala encyklopedie rabinskeho judaismu. Libri: Praha. ISBN: 97880-7277-379-4.

SUSMAN, M. Das Buch Hiob und das Schicksal des judischen Volkes. 978-363354-115-7

VRIES, S. P. 2008. Zidovske obrady a symboly. Praha: Vysehrad. ISBN 978-807021-963-8.

\section{Internetové zdroje:}

Ibn Ezra's Torah Commentary: Available online:

http://mg.alhatorah.org/Dual/Ibn_Ezra_First_Commentary/1.1\#t1e0n6, 12.07.2017.

Available online: http://www.daat.ac.il/daat/vl/tohen.asp?id=388Chayei Adam fulltext, 12.07.2017.

Chajej adam, Available online: http://www.daat.ac.il/daat/vl/tohen.asp?id=388Chayei Adam fulltext, 30.5.2016.

Rashi's Torah Commentary, Available online: http://alhatorah.org/Commentators:Rashi_Leipzig_, 12.07.2017.

משנה תורה להרמב"ם, Available online: http://www.mechon-mamre.org/i/0.htm, 12.07. 2017

, Available online: http://www.mechon-mamre.org/b/h/h0.htm, 12.07.2017.

Mišna berura, Available online: http://mishnaberura.eu5.org/, 12.07.2017. 
שישה סדרי תוספתא Available online: http://www.mechon-mamre.org/b/f/f0.htm, 12.07.2017.

שישה סדרי תלמוד בבלי Available online: http://www.mechon-mamre.org/b/l/10.htm, 12.07.2017.

Shulchan Aruch Harav. The Alter Rebbe's Shulchan Aruch - Code of Jewish Law, Available online:

http://www.chabad.org/library/article_cdo/aid/3127874/jewish/Shulchan-AruchHarav.htm, 12.07. 2017.

Available online: http://www.Torah.org/advanced/shulchan-aruch/. 10. 1. 2009.

Shulchan Arukh, Orach Chayim | Sefaria

Available

https://translate.google.cz/translate?hl=cs\&sl=iw\&u=https://www.sefaria.org/Shulcha n_Arukh,_Orach_Chayim\&prev=search, 12.07. 2017.

תלמוד ירושלמי Available online: http://www.mechon-mamre.org/b/r/r0.htm, 12.07.2017.

Available online: http://www.mechon-mamre.org/i/t/u/u0.htm, 12.07.2017.

Words: 3371

Characters: 22149 (12,31 standard pages)

Prof. Dr. Roman Králik, ThD.

Faculty of Arts, Constantine the Philosopher University in Nitra,

Hodzova 1,949 01 Nitra

Slovakia

rkralik@ukf.sk

ThDr. Marie Roubalová, ThD.

Hussite Theological Faculty, Charles University in Prague,

Pacovská 350/4, 14000 Praha

Czech Republic

marie.roubalova@htf.cuni.cz

Prof. PhDr. Ladislav Lenovsky, PhD.

Faculty of Arts,

University of Ss. Cyril and Methodius in Trnava,

Nám. J. Herdu 2, 91701 Trnava

Slovakia

ladislav.lenovsky@ucm.sk

Tünde Tuska, PhD.,

Szlovák Nyelv és Irodalom Tanszék, Nemzetiségi Intézet, Juhász Gyula Faculty of Education, University of Szeged

Boldogasszony sgt. 6., 6725 Szeged,

Hungary

tuska@jgypk.u-szeged.hu

Dr. Sc. Sandra Kralj-Vuksić,

Slovački centar za kulturu Našice,

Braće Radić 68, 31500 Našice,

Croatia

slovackicentar-ravnatelj@os.t-com.hr 